\title{
Elections in Canada and Russia in 2019: a comparative analysis of cross-national media coverage
}

\author{
Anna Tsurkan ${ }^{1}$ \\ Canada-Russia Research Initiative
}

\begin{abstract}
In 2019, Canada and Russia both went through election campaigns; Russia held regional and municipal elections in September, while Canadians voted at the federal level in October. This article examines cross-national media coverage during the two election campaigns in order to provide a snapshot of the positions and perceptions each country has about the other's electoral and political processes. The purpose is to identify and explain over-arching narratives that frame each country's media discourse about the other, as media from the two countries were actively involved in cross-commenting about the situation on the ground as the election campaigns took place and after results were reported. However, the content of Canadian and Russian reporting differs greatly, in part because of the different levels at which the elections occurred, but more importantly due to differences in underlying assumptions and biases on both sides. While these differing narratives remain in place, it is unlikely that media, and by extension, public opinion about the other country will shift.
\end{abstract}

\footnotetext{
${ }^{1}$ Anna Tsurkan is a Founder and Project Coordinator of the Canada-Russia Research Initiative.
} 


\section{Introduction}

In 2019, Canadians and Russians went through election campaigns in their respective countries. Canada held a general election in October, which resulted in a minority government led by Justin Trudeau. A month earlier, Russia undertook elections of heads and legislative bodies in many regions and municipalities, as well as a number of by-elections at all levels of government. Voters in 70 out of 85 regions of the Russian Federation went to the polls, which outnumbers Canadian voters in absolute figures. In comparing the two election campaigns, the level of each election is an important factor, as, in Russia, there were multiple separate campaigns at the local and regional levels, each with its own issues and agendas. The Canadian election, on the other hand, was conducted across the nation to determine the next federal government. Examining these two 2019 elections allows us to take a snapshot of Canada-Russia relations at a given moment in time, providing insight into mutual perceptions of the other's electoral processes. This article analyzes pre-election discourses, media coverage, and commentary, and examines the extent to which disinformation campaigns took place on either side.

Canadian and Russian media outlets were actively involved in cross-commenting about the situation in each other's country in 2019. But this coverage was rather disproportional. On the eve of the Canadian federal election campaign, a number of media and research-based analyses (Global News 2019; Jardine 2019; Al-Rawi and Jiwani 2019; Kolga 2019a) suggested the high probability of Russian interference, especially in light of the American investigation into Russian meddling during the 2016 United States (US) presidential election. During the pre-election period in Canada, an anti-Russian discourse portraying Russia as a potential threat to Canadian democracy became one of the dominant themes linked to discussions of election security in the Canadian context.

The anti-Russian media narrative in Canada provoked a boost in anti-Canadian rhetoric in Russia. This contrasted with the traditionally low level of coverage of Canada as a topic for analysis in the country. Russian media did not suggest that Canada was a threat to Russian elections, which contrasts with the dominant narrative of a Russian threat by Canadian media, yet nonetheless, articles about Canada in general, and the Canadian reaction to the Russian elections in particular, were negative in tone even while being sporadic in distribution. Nevertheless, the bi-lateral relations between the two nations were further strained by a short Canadian Twitter campaign in the midst of pre-election opposition rallies in Moscow. Speaking up against mass detentions, Canadian authorities called on their Russian counterparts to respect freedoms of assembly which enmeshed the two foreign agencies in Twitter diplomacy on the issue.

Taking into consideration the above-mentioned context and the research task to compare media coverage, this paper is divided into three sections. The first section discusses how a Russian factor in the form of non-interference was projected by Canadian media outlets as one of the main pillars of free and fair election in the country. The second part looks at Russian media frames about the 2019 general election in Canada. And, finally, the final section analyzes how Canadian journalists covered regional and municipal elections in Russia. The conclusion provides the main findings on cross-national media coverage.

Although the question of election interference is extensively discussed in this article, it does not represent the subject of the research. Media coverage could be considered one of the aspects of election meddling, however, other aspects such as spreading misinformation through social media, 
cyberattacks on politicians and government institutions, intrusions into election systems, and financing favorable candidates are far more serious allegations indicative of actual interference. Thus, both interference and non-interference are examined in this context as topics of media coverage influencing people's perceptions, but the validity of the various claims is not assessed in this article. The research question rather relates to how media discourses and contexts differ in the two countries.

\section{Methodology and Theoretical Foundation}

The notion of 'media cross-coverage' is utilized in this paper in addition to a number of standard terms used in the communications field, such as 'media coverage' and 'media discourse'. Media cross-coverage refers to media coverage and discourse of pre-election and election campaigns in the two countries in a cross-national commenting format. As opposed to self-coverage, where self is seen as the country of origin of any given media outlet, cross-national coverage is applied to coverage of the other, in this case Canadian media coverage of Russia and Russian media coverage of Canada. Furthermore, the cross-commenting does, in fact, sometimes transgress the bounds of simple media coverage and includes state officials on various levels making statements on positions and/or actions of their counterparts. In this analysis, statements connected to the substance of this research are analyzed as a part of a framing concept in media, as media content is produced in a continuous interaction between journalists and elites (De Vreese 2005, 52-3). In addition, nowadays, any politician in either country can actively participate in a frame-building process by means of social media. This paper specifically focuses on Twitter, which has become not only a new tool of digital diplomacy, but also one of the primary sources of troll-generated content aiming to either spread disinformation and/or to create an illusion of public discourse (Chamberlain 2010, 16).

In terms of methodology, this research draws from both political science and communication studies. Taking media content (mainstream as well as social) as the main data for study, both qualitative and quantitative approaches were implemented in content analysis and comparative analysis relative to classical political science theory (Wilkerson and Casas 2017, 530). In turn, a media framing assessment was conducted based on deductive and empirical communication approaches (De Vreese 2005, 53-4).

The data collection and text analysis were implemented manually, with the content being drawn from media broadcasts and official statements from Russian and Canadian sources in Russian and English. ${ }^{2}$ As the main body of this article is divided by elections in Canada and Russia, a systematic study of major Russian ${ }^{3}$ and Canadian ${ }^{4}$ media outlets was conducted on a regular basis from June,

2 Canadian sources in French stayed beyond the scope of this project, which creates an additional opportunity to analyse differences in English and French media coverage of Russia in Canada in a separate study.

${ }^{3}$ Channel One Russia, Dozhd, Interfax, Izvestia, Russian News Agency, TASS (Telegrafnoye agentstvo Sovetskogo Soyuza), Kommersant, Moskovskij Komsomolets, Nezavisimaya Gazeta, Novaya Gazeta, RIA (Rossiskoe Informatsionnoe Agentstvo) Novosti, Russia 1, Vedomosti, Vesti, Vzglyad.

${ }^{4}$ The Canadian Broadcasting Corporation (CBC), CTV, Global News, Globe and Mail, National Post. 
2018 to November, 2019 to gauge cross-national coverage of pre-election and election campaigns, as well as election results in both countries. For the same period of time, in the interests of tracing diversity in the existing media discourse on the issue together with an evaluation of the initial stages of media framing and the identification of media content from lesser-known sources, a news search was run through Google.ca in English and Yandex.ru in Russian, with 'elections in Russia' and 'election in Canada' as key phrases. In addition, publication tracking on websites and social media accounts of Global Affairs Canada and the Russian Ministry of Foreign Affairs, as well as other governmental institutions participating in Canada-Russia relations, was actively used for gathering information for content analysis and framing assessment.

Examination of Russian media coverage of Canada identified the existence of two separate categories of broadcasting. These two categories are examined separately in this paper because the target audience as well as goals of reporting were found to be different. The first category addresses Russian-language media directed at a Russian-speaking population both in and outside of Russia, while the second looks at English-language outlets, in particular, $R T$ (a rebranded version of Russia Today), which is available in Canada online and through all major cable providers, and Sputnik, which is available online. Both media outlets are widely associated with the Kremlin's propaganda (Van Herpen 2015; Oates 2016) and information warfare (Lough et al. 2014). Canadian media coverage of Russia, which was only in English, contrasted with the Russian approach, which published both in English and in Russian.

Speculations about potential Russian meddling in the 2019 federal election in Canada were widespread in Canada, and theoretical and analytical works were published about the issue (AlRawi and Jiwani 2019; Bradshaw 2018; Jardine 2019; Kolga 2019a; 2019b; 2019c; Sukhankin 2019). This present study builds on these sources and supports some of their conclusions. However, the author's own experience working in the field of international election observation and election management, both in Russia and in Canada, enriches this article with insights on the essence of the electoral process in the two countries.

\section{Canadian Media Coverage of the 2019 General Election: The Threat of Russian Meddling}

Despite the absence of party leaders' debates on foreign policy during the 2019 election campaign, Russia played an important role in the campaign. Candidates generally criticized Russian actions on the world stage, particularly in relation to events in Crimea and Ukraine in 2014. However, in comparison with the 2015 election campaign, there was a shift from international to national issues and, in particular, to the issues of national cyber security. In this regard, Canadian journalists, analysts, politicians, and state institutions placed the potential threat of Russian meddling in the election at the centre of the discourse about freedom and fairness of elections in Canada. Thus, protection against foreign interference was framed as one of the main pillars preserving the Canadian democratic process.

\section{Pre-Election Period: Framing the Narrative}

A focus on election interference was initiated by the media in response to the US investigation into Russian meddling during the 2016 American presidential election, and in conjunction with disruptive actions conducted by St. Petersburg's Internet Research Agency, commonly known as 
the 'Russian troll factory', which produces content in the name of domestic users in foreign countries. A cache of three million deleted tweets associated with Russian trolls (based on their account information) was made public by the US House Intelligence Committee (US House of Representatives 2018). Two professors from South Carolina's Clemson University collected all tweets (Linvill and Warren 2018, 3) and shared them with FiveThirtyEight website (Roeder 2018). Having searched this database for 60 keywords connected with Canadian issues, $C B C$ journalists revealed in August, 2018 that almost 8,000 Russian tweets had targeted Canada between June, 2015 and December, 2017 (Rocha 2018). Following this media report, a national survey commissioned by $C T V$ showed that 69 percent of Canadians found it credible that the Russian government was using social media to meddle in western democracies (Nanos Research 2018, 2$3)$.

The two major Canadian media outlets, $C B C$ and $C T V$, not only allowed the narrative of a potential Russian interference in the 2019 election in Canada to emerge, but also reinforced it by evaluating people's perceptions on this matter. The election meddling narrative became theoretically and linguistically conceptualized, with the majority of its concepts being used further in the course of the election campaign. In addition to widely used terms like 'disinformation', 'meddling' and 'interference', certain keywords and ideas that continued to emerge from the initial $C B C$ article (like, 'target Canadians', 'sow discord', 'polarizing content', 'threat to democracy', etc.) indicate the existence of this narrative that could be found in subsequent media discourse.

From August, 2018 to August, 2019, dozens of analyses predicting foreign interference in the 2019 federal election in Canada appeared (Al-Rawi and Jiwani 2019, Jardine 2019, Kolga 2019b, 2019c). Several more waves of tweets showcasing the interests of Russian trolls in Canadian domestic policy were released. A number of research papers on how to secure the election from disinformation coming from abroad were published by researchers and by state security agencies (Bradshaw 2018, Communications Security Establishment 2019, Kolga 2019a). But, more importantly, the issue was raised at the highest level. In September, 2018, Canada's Prime Minister Justin Trudeau, when asked by a journalist, denied direct Russian interference in the 2015 Canadian election. However, he admitted that Canada was aware of and had taken actions to prevent such a possibility in 2019 (Council on Foreign Relations 2018). In April, 2019, he went further. Speaking to reporters in Toronto about divisive campaigns in social media conducted by "countries like Russia," he re-affirmed that the task of the government was to ensure noninterference in Canadian elections (Global News 2019).

The 'Russian threat' narrative continued to amplify during the campaign, with contributions from analysts, politicians, state institutions, and media. The Government of Canada developed and announced a plan to protect Canadian democracy in January, 2019. This plan was based on four pillars: informing voters about online threats; engaging social media platforms in tracking disinformation; activating intelligence; and coordinating government institutions' role in security provision (Government of Canada 2019). The 'Get Cyber Safe' campaign was conducted by a newly-created Canadian Centre for Cyber Security, and seven million dollars were allocated by the government toward digital, media, and civic literacy programming (Government of Canada 2019). Nevertheless, alerting the public to the probability of foreign meddling fell largely to news media outlets and politicians who communicated their messages through mass media and social media. Previous media research has identified the significant role played by the media in alignment with the government's objective of informing the electorate (Druckman 2005, 476-7). 
A regular news search through Google.ca during this pre-election period detected only two Canadian texts counter-arguing the predominant anti-Russian discourse (Climenhaga 2019; Nelson 2019). Both of these texts were published in April, 2019 after Trudeau's above-mentioned comments about foreign disinformation campaigns on social media. Mocking the election meddling narrative, both authors disputed Trudeau's politics, stating their intention not to support the Prime Minister and the Liberal Party during the 2019 general election. The existence of this counter-narrative speaks in favour of public and media pluralism, nonetheless the narrative of Russian interference was clearly dominant. Climenhaga's article was posted on a personal blog and Nelson's in the Calgary Herald. The absence of similar messages in mainstream national media outlets in Canada is an indicator that their point of view was an outlier (Chomsky 2002, 29).

\section{Election Campaign and Election Day: Expectations vs. Reality}

The election campaign in Canada officially started on September 11, 2019. The narrative of potential Russian interference was soon eclipsed by campaign scandals and debates among election contestants. Russia, or relations with Russia in any form, were hardly ever mentioned by candidates or their political parties. This is explained partly by the lack of a separate debate on Canadian foreign policy. The only event which had been scheduled - the 2019 Munk Debate on Foreign Policy - was cancelled due to Trudeau's absence, in spite of the fact that the other three leaders of major parties, including Elizabeth May (Green), Andrew Scheer (Conservative) and Jagmeet Singh (New Democratic Party) confirmed their participation. Two other leaders' debates involving all six party leaders were organized by a Leaders' Debate Commission as an integral part of Canada's federal election, one in English and another one in French; these debates focused on internal Canadian politics, as did the entire election campaign.

The only event where a Russian issue came up was the National Leaders' Debate held by Maclean's and CityTV. The question was raised by Paul Wells, a moderator and Maclean's senior writer, and addressed Elizabeth May's proposal to shift Canadian focus and funding away from NATO in spite of "Putin's military muscle flexing" (Maclean's 2019). Among the three leaders who participated in this event, Russia was mentioned only by May and Andrew Scheer in their responses, while Jagmeet Singh addressed another topic. May spoke briefly about Putin's efforts to increase Russian nuclear capabilities and Canadian lack of surveillance on its Arctic shores to intercept Russian vessels, while Scheer concentrated on the Russian government's actions in Ukraine and Crimea and promised to support Ukrainians in their "fight against the Russian aggression." The Conservative leader, who was the House of Commons speaker at that time, had been banned from travelling to Russia under retaliatory sanctions on 13 Canadian officials issued by Putin back in March, 2014.

When the 2019 federal election took place, the question of whether there had been interference remained open for a while. It was clear right away that the Critical Election Incident Protocol, created specifically to decide if a level of disinformation was high enough to notify citizens and compromise elections, was not activated. However, despite the fact that the threshold to threaten the integrity of the election was not met, Canadian officials declared that some malicious activities were detected (Thompson 2019). Although the details were expected to be made public in spring 2020, the Elections Canada report came out earlier, in mid-February. The document repeated the pre-election security concerns and measures taken by the agency to address them, including the Social Media Monitoring Unit operating in 21 languages to detect disinformation. This particular 
unit flagged only 28 pieces of both misinformation and instances of impersonation of Elections Canada between August and the election day, which "could have interfered with electors' ability to vote" (Elections Canada 2020, 57-9). Other than that, no cybersecurity incidents were found to have influenced the electoral process.

Similar estimates about the scope of foreign election interference had been presented to the public earlier by media outlets with a reference to other stakeholders monitoring potential disruptive actions online. For example, the $C B C$ reported that Facebook Canada's global director and head of public policy, Kevin Chan, did not see signs of election meddling on their platform (Thompson 2019). The $C B C$ also published an article titled "Fears of election meddling on social media were overblown" (Rocha 2019), sharing research results of the Digital Democracy Project, the Ryerson Social Media Lab, and the University of Toronto's Citizen Lab. Thus, despite high-profile international investigations into Russian meddling in foreign elections in the US and France, and the constant discourse of possible Russian interference in the Canadian federal election, evidence brought out in the media indicated that election-meddling never moved from a potentiality to an actuality.

Significantly, public discourse on interference versus non-interreference in the 2019 general election in Canada was focused on either direct cyberattacks or social media trolls. (Dis)information and/or messages in favour or against certain election contestants spread by foreign media broadcasters were not taken into consideration, nor were they counted for the purposes of official statistics, despite the fact that tracing this type of materials is essential for a comparative analysis of media cross-national coverage. The examination of this data is described further in the section about Russian English-language media. But, at this point, it seems important to note that what we count as cases of foreign meddling in the internal politics of a sovereign state, and how we count them, finally, produces our definition of interference. In 2019, Canada seemed to exclude media broadcasting from their understanding of foreign interference.

\section{Lessons learned}

Examining the goal of media warnings about potential Russian election interference reveals a paradox. On the one hand, the strategy of highlighting such threats was apparently based on the assumption that the more information the media provide about the potential threat, the more protected Canadian voters will be. On the other hand, there is no research on the effects of this framing, including information processing effects as well as attitudinal and behavioral effects (De Vreese 2005, 52). Also unclear is the type of data that could be used to evaluate such effects. Unlike a variety of studies looking at how Russian trolls contributed to polarization of conversations on social media, studies have not detected a direct correlation between media content and voters' behavior (Gallacher and Heerdink 2019; Kriel and Pavliuc 2019). National surveys and anthropological research conducted in a timely manner might have helped to reveal some interesting linkages.

In the meantime, several extracts from the Elections Canada internal social media monitoring report released by the $C B C$ indicate a relatively high-volume of discussions among Canadians questioning the legitimacy of the 2019 election (Burke 2020). Among the major concerns, directly or indirectly connected with the meddling narrative, were: a) an alleged potential for non-citizens to vote sparked by Elections Canada's report of removing more than 100,000 non-Canadians from voters' lists and by questioning the existing ID requirements for voting; b) speculations about the 
release of compromising materials about candidates, in particular Justin Trudeau, which could have been an indication of foreign media interference in the election campaign; c) other instances of election-related commentary from foreigners. Thus, the Canadian electorate, as determined by the Elections Canada's Social Media Monitoring Unit, was partially concerned about the appropriateness of foreign opinions, including media broadcasting coming from outside of the country, during the election campaign period. In turn, Elections Canada had to remind voters that election law permits people outside of the country to give their views on topics related to Canada's election (Burke 2020).

\section{Russian Media Coverage of the 2019 General Election in Canada: Trudeau's Hypocrisy and the Decline of Liberal Democracy}

In contrast with Canadian broadcasters, which do not publish in Russian language, their Russian counterparts have both English-language and Russian-language media outlets. Their target audience as well as goals of reporting were found to be different which slightly affects the existing narratives. This section explores Russian media frames about the 2019 election in Canada in both types of broadcasters.

\section{Canada in Russian-Language Media and Political Discourse}

For traditional media outlets and institutions in Russia, Canada is not a very popular topic for analytical coverage. Despite a firm anti-Russian stand on most of the issues in the international arena adopted by Canada since 2014, the country is mostly perceived by Russian foreign agencies and portrayed in the Russian media as dependent on the US. The predominant discourse in Russia sees Canadian eagerness in foreign policy matters strongly interconnected with US foreign policy. Canada is presented as being either influenced by the US or attempting to outdo the US (Ministry of Foreign Affairs 2019), but almost never as an independent player. However, Russian elites enjoy much more power in this frame-building process in media in Russia than their Canadian counterparts in Canada (De Vreese 2005, 52), which allows us to claim that the Russian authorities promote narratives about Canada which are transmitted by media, shaping public opinion to a certain degree.

In response to anti-Russian frames put forth in Canadian media, a similar boost of anti-Canadian discourse was apparent in Russia. On January 13, 2019, Canada unexpectedly became an object of a ten-minute-long TV report prepared for Dmitry Kiselev's weekly news on Russia 1. Kiselev, the only Russian journalist sanctioned by Canada for propaganda, charged the Canadian government with falling under the strong influence of the Ukrainian lobby within its borders (Lyadov 2019).

The dissemination of a Russian state narrative is often depicted in the West as propaganda (Jowett and O'Donnell 2018, 6). In this view, Russian-language media mostly represent a platform for the government to maintain a desired level of support among its citizens. Media discourse is also depicted as being connected to national identity in the sense that if patriotism becomes a concept monopolized by the Kremlin, those who do not support the state can be labelled unpatriotic, denying them any opportunity to criticize either the government or the dominant narrative (Oates 2014, 3). 
This new form of Russianness cannot help influencing Russian speakers abroad. Researchers suggest the particular interest of Russia is to reach out to its citizens who reside outside of the country to promote the idea of a 'Russian world' (Kozdra 2018, 63). However, in some ways this re-connection with the Russian state media frames happens naturally. Some segments of Russianspeaking people abroad watch Russian-language television and read Russian-language newspapers online. Ongoing negative messages about Russia in countries of their residence surely affects their Russian national identities. As Chris Nelson from the Calgary Herald points out, "it is a tad annoying to constantly see your native land being blamed for every problem on earth" (2019). Thus, in their attempts to defend these national identities, Russians abroad may become prone to accepting narratives coming from Russian broadcasters.

According to the 2016 Census, 622,445 people in Canada claimed Russian ethnic origins (2016). A few television providers offer Russian state-channel packages. Russians living in Canada can also access the same channels and a wider range of resources produced in Russia online. It is not possible to estimate the exact number of Russians in Canada regularly following the Russian media, although the majority stays consciously or unconsciously exposed to the Russian content if they read anything in Russian on the Internet. This content contains media frames, most of which would inevitably contradict those which circulate in Canada.

Recipients of the Russian state narrative in Canada are accused of spreading the Kremlin's propaganda if they wish to share any contradictory messages or speak up in favour of the Russian regime (Kolga 2019, 29-31). The Russian Congress of Canada (RCC) expressed its discontent with being labeled as a 'white propaganda' outlet or being pro-Putin (RCC 2019a). This diaspora organization tried to prove its ideological and financial independence (2019a) and defend its right to represent Russian-speaking community interests, including before the Government of Canada (RCC 2019b).

Although the Russian community in Canada is clearly under-studied by researchers, the RCC example demonstrates the adverse effect of seeing pro-Russian sources or associations as deliberately propagandist unless they take an anti-Putin stand. Such an interpretation would make the entire Russian diaspora an outcast associated either with the Kremlin's funding, or depicted as being driven by its propaganda. In these circumstances, Canadians of Russian ethnic origin might feel deprived of their right to participate in any activities related somehow to the Russian state or to defend any pro-Russian position without being labeled propagandists. Such exclusion forces them to make a choice in between Russian and Canadian discourses, while the media environment becomes extremely polarized.

Meanwhile, the more stakeholders in Canada got involved in an anti-Russian discourse, increasing the volume of media broadcasting about potential election interference, the more the Russian press broke its previous silence in analytical coverage of Canada. In April and May of 2019, three articles were published by Filippov, with two appearing in the newspaper Vzglyad. In addition to being a regular contributor to Russian news outlets, Filippov works at the Centre of Applied Research and Programs in Moscow which specializes in consultation and analysis, with a separate focus in managing election campaigns in Russia, Abkhazia, Belarus and Ukraine (PRISP, n.d.). In an overly-free and caddish tone, Filippov accused Canada of meddling in elections abroad, of committing cultural genocide towards its First Nations, and of playing the Russian card in order to hide its own corruption scandal with SNC-Lavalin (2019b; 2019c). As examples of Canadian election interference, Filippov mentioned Canada's role in toppling the regime in Ukraine in 2014, 
its further military and economic support of the country, and Canada's efforts to support Juan Guaido in Venezuela (Filippov 2019a). His main idea was to show Russian readers that although Canada blamed other international actors for their attempts to influence different countries, it has never admitted to the same in its own politics.

Filippov's articles illustrate the counter-narrative with which Russian media responded to an increase in the intensity and volume of Canada's anti-Russian stance. The Canadian rhetoric about Russia could not simply be ignored in a modern highly interconnected world where information flows relatively freely. Paraphrasing Oates' dilemma $(2014,9)$, if you can't ignore the Canadian frames, how do you try to shape them to fit the strategic narrative? The algorithm included the use of the same frames against the counterpart, by adding counterarguments and further details to support them. Distinctively for this type of reporting, being portrayed through the strategic lens, it often contains a significant fraction of truth (Paul and Matthews 2016, 5). However, a blend of facts which an average consumer would know very little about raises credibility concerns.

Like in Canada, not all the reporting in Russia follows the dominant script. For example, in January, 2019, Nezavisimaya gazeta published an article by Akimushkina, a Russian expert in Canadian studies, who wrote that Canada is not "a Northern extension of the USA" (2019). She not only accurately described Canada's stance on Russia, but also factually contradicted the Foreign Ministry's notion about Canada's dependent foreign policy. That this sort of material was published by a state-affiliated newspaper might seem confusing in the context of state-controlled Russian media. Nonetheless, it happens occasionally and might reflect either a lack of interest by the authorities in print media, or their own way of challenging certain narratives to test public opinion.

Canadian election campaign coverage in Russian media started a day earlier than the official campaign in Canada. On September 10, 2019, RIA Novosti, an original RT founder and a part of the international information agency group Rossiya segodnya, published an article about rising negativity surrounding Justin Trudeau on the eve of the election campaign in connection with the SNC-Lavalin corruption scandal (Kornilov 2019). The author clearly attempted to undermine the current Canadian Prime Minister by citing Spencer Fernando, a frequent contributor of antigovernment pieces to the Post Millennial. ${ }^{5}$ The Russian media outlet claimed that $C B C$ News was taking Trudeau's side because of the broadcaster's funding boost generated by the Prime Minister. All this information was given to suggest hypocrisy among Liberal Canadian politicians and their form of democracy.

Keeping in mind that RIA Novosti as a part of Rossiya segodnya is included on a list of Russian strategic enterprises and is treated as a pro-Kremlin media resource, materials produced by this news outlet must be seen in a broader framework of internal and external information campaigns (Sukhankin 2019, 9). Russian speakers both in Russia and in Canada are meant to receive a portion of the Russian state narrative through such exclusively online pieces of information. Thus, they

5 Canadian news platform founded in 2017 in Montreal and portraying itself as a "reasonable alternative" (The Post Millennial 2020). 
inevitably contain pro-Russian messages about how, in this case, Canada is far from being truly democratic.

Nevertheless, the Russian-language media coverage of the Canadian election campaign was not very dynamic. While Justin Trudeau appeared in newspapers' headlines several times during this period, the Russian press mostly reacted discreetly to the campaign scandals exposed by the Canadian press. In particular, an increase in media activity was noted in connection with the release of pictures of Trudeau wearing blackface makeup in the past. Other than that, the Russian media rather neutrally reported the election results, once again coming back to a general lack of interest in covering Canadian stories.

\section{Russian English-Language Media Coverage of Canadian Election Campaign}

In April, 2019, the predominantly anti-Russian rhetoric in Canada resulted in a small-scale Twitter diplomacy response on alleged charges initiated by the Russian Embassy. The Embassy denied any allegations via its Twitter account. The accusation of the impending election meddling was stated as being "fake," adding to the disinformation campaign against Russia. "Given \#RussiaGate fiasco in the US, it's ridiculous to play the same card in Canada to distract public attention from real issues," tweeted Russian diplomats (2019).

The Russian Embassy, not unexpectedly, is viewed in Canada as promoting the official Russian discourse. Messages coming from the Embassy resemble frames used in Russian media outlets, both in their tone and format of delivery. It is equally true with regard to the Canadian Embassy in Russia which represents Canadian views and follows the country's official narrative. Russian news outlets broadcast in Canada in English to appeal to a broader English-speaking audience, whereas Canadian media do not broadcast in Russian. Thus, while Canadian media frames are directed primarily internally, Russian English-language narratives are directed at an external audience to challenge those of western media. This state of affairs leads their western counterparts to define these types of Russian information sources as propagandists (Paul and Matthews 2016, 2).

Despite the fact that even the Russian Ministry of Foreign Affairs repeatedly intervenes in the public discourse defending Russian English-language media outlets, such as $R T$ and Sputnik, both of which are connected under the umbrella of Rossiya segodnya, Vladimir Putin, when talking about the creation of $R T$, specified that the intention was to introduce "another strong player on the international scene [to] provide unbiased coverage of the events in Russia" and to "try to break the Anglo-Saxon monopoly on the global information streams" (Putin 2013). Moreover, according to the Russian President, as this media outlet receives state funding, "it cannot help but reflect the Russian government's official position on the events in our country and in the rest of the world one way or another."

Although both Sputnik and $R T$ published articles during the Canadian election campaign, the volume of these two outlets was quite different. Sputnik issued only three major articles, two of which retranslated the actual campaign scandals and debates, including Trudeau's blackface makeup and Scheer's dual Canadian and US citizenship. The third piece was more specific, showcasing election candidates from various provinces. Notably, the author of this text called Maxim Bernier, together with his newly formed People's Party of Canada "a powerful new player," contrasting with Canadian mainstream media depictions of Bernier, which generally described him as populist (Bolotsky 2019). After election day, Sputnik shared a video of an Imam 
from British Columbia appealing to his congregation to boycott the vote, accusing all the candidates of being "evil" in their approval of homosexuality and supporting "the Zionists against Islam and the Muslims" (Korso 2019).

$R T$ 's Canadian election coverage was much higher in volume, and more anti-Trudeau in nature. On the blackface matter alone, $R T$ produced four articles on September 19-20, 2019, which were shared on Facebook more than 600 times. Through all of them, the Canadian Prime Minister was depicted as a hypocrite, a liar, and a "self-proclaimed champion of "liberal values"" (Cunningham 2019). The same negative depictions of Trudeau in particular, and liberalism in general, were repeated by $R T$ in its op-eds on September 27, October 7, and October 16, right up to the election day, and shared on Facebook more than 1,000 times. The articles on Trudeau were supplemented with a history of First Nations marginalization, the SNC-Lavalin corruption case, and broken election promises (Vivanco 2019a).

Additionally, $R T$ covered more topics than did Sputnik, shoring up the Canadian hypocrisy narrative through stories about tensions with the Philippines because of the Canadian plastic trash, the disrespectful behavior of Antifa protesters outside Mohawk College in Hamilton, Trudeau's bulletproof vest worn at one of the campaign events, Air Canada's decision to apply "everyone" as a gender-neutral form of greeting, and a former Playboy model with Polish roots contesting the election on behalf of the People's Party of Canada. And, finally, all the allegations against the current Prime Minister were repeated in the $R T$ News block on October 16. Compared to coverage of Trudeau, other election contestants were covered minimally by the outlet. When Trudeau won the election, $R T$ portrayed his victory as a lack of competition and a broken electoral system (Vivanco 2019b).

Knowing that $R T$ is available in Canada on a variety of basic news packages, its narratives about this country definitely reach the Canadian audience, although the exact number of viewers is unknown. Their articles went far beyond the original $R T$ and Sputnik mandates to improve Russia's image abroad; they easily fall under the category of promoting political polarization in the recipient country. They had the potential to influence voters' behavior and could be construed as a disinformation campaign or election interference, but it is difficult to assess their effectiveness without further research.

\section{Canadian Media about Regional and Municipal Elections in Russia: Concerns Over Political and Electoral Freedoms}

The summer of 2019 was marked by regional and municipal election campaigns in the majority of Russian regions, with the elections held on September $8^{\text {th }}$ across the country. In contrast to Canada, a threat to the integrity of election is perceived somewhat differently in the Russian context. Moreover, these perceptions vary, in general, among stakeholders. Election integrity is measured by the Russian authorities as stability for the existing regime, as opposed to pure freedom and fairness of the election. Considering widespread demands for free and fair elections in 2011, and the importance of this for an evolving civil society in Russia, this concept of stability can be understood as a form of the Kremlin's interference in elections in its own country. 
In terms of the electoral process, this interference is often expressed in registration barriers and denials of oppositional candidates, misuse of administrative resources, and inequitable media coverage, as well as election day fraud reported by numerous international and independent domestic observers. ${ }^{6}$ An 'electoral fallacy' has been described as an integral part of Putin's first two terms, and has been traced back to the Yeltsin era and the Soviet Union (Evans 2011, 42-3). Beyond the electoral process, this fallacy is rooted in the state of the political system in Russia. The opposition in the country is extensively covered as driven by external forces. They are presented as the "fifth column" funded by the US State Department, while people who express their opposing views through participation in activism in person or online are exposed to political persecution (Katorzhnov 2014; Martinov 2011; Pinchuk 2019).

\section{Media Coverage and Twitter Diplomacy}

Election campaigns in Russia officially started on May 30, 2019. By then, prominent opposition figure Alexei Navalny had been promoting his new voting initiative 'Smart Vote' for half a year. The idea of this project was to encourage voters to support the strongest candidates despite their party's affiliation, to win a victory over election contestants associated with United Russia (Navalny 2018). Navalny and his team identified candidates in various electoral districts across the country, based mainly on previous election results. This data was made publicly accessible to voters online. Beyond that, Navalny's Anti-Corruption Foundation endorsed a number of election contestants in several Russian regions. None of these activities were covered by Canadian media outlets until a series of demonstrations occurred after the official denial of registration for opposition candidates aiming to contest the 2019 Moscow City Duma election.

After the first rally on July 20, 2019 gathered around 22,000 people, subsequent protests were not authorized by the City administration. ${ }^{7}$ This is when the media coverage by Canadian broadcasters began. On July 27-29, Canadian media outlets reposted news articles originally published by Reuters and Associated Press about massive arrests in Moscow and the suspected poisoning of Alexei Navalny. CBC, CTV and Global News all discussed the situation in Moscow in their televised news reports. Their stories about the Kremlin's involvement referred to a series of similar alleged operations, including poisonings of Sergey and Yulia Skripal, Alexander Litvinenko, and Viktor Yushchenko.

The first article about the events in Moscow appeared in the Globe and Mail on July 30, written by American author Amy Knight (2019). ${ }^{8}$ Knight, together with another leading American researcher, William Pomeranz, presented their vision on CTV News earlier. More American

\footnotetext{
${ }^{6}$ The respective conclusions on the essence of these allegations of election violations are based on findings and reports of the following election observation missions and groups: OSCE/ODIHR, OSCE PA, PACE, Golos, League of Voters, Citizen Observer, Sonar, For Clean Elections and National Civil Monitoring. This data from 2011 to 2018 election campaigns in Russia can be found on the Internet and is not included into bibliography of this paper. In addition, having served as a member with a decisive vote of a precinct election commission in Moscow during 2013 and 2014 regional elections, the author of this article witnessed several attempts and some particular cases of election violations.

${ }^{7}$ An authorisation is required for any type of protests except for an individual one, according to the Russian legislature.

${ }^{8}$ The use of US experts on Russia in Canadian media outlets is very common and they are interviewed extensively.
} 
experts shared their points of views on Global News, questioning Putin's role in this whole story (Pazzano 2019). Global also introduced to the Canadian audience that more Russian regions had rallies of the same sort. The Russian Smart Vote initiative appeared in the information environment in Canada only a couple of days prior to the election day, on September 6, 2019. Notably, the Globe and Mail interviewed exiled Russian oligarch Mikhail Khodorkovsky, who called on voters to support only "genuine" opposition candidates in contrast to Navalny's plan (Mackinnon 2019a).

On July 29, 2019, by means of its Twitter, Global Affairs Canada (@CanadaFP) expressed grave concerns over the detention of more than a thousand participants in a pre-election opposition rally held two days previously in Moscow. The Canadian agency referred to the Russian constitution, which includes such fundamental rights as freedom of assembly and expression. Canadians called on "Russian authorities to respect these rights and refrain from violence" (July 29, 2019). In response, the Russian Ministry of Foreign Affairs (@mfa_Russia) recalled clashes between Canadian demonstrators and local police forces in Quebec City in March, 2015 (July 30, 2019). This exchange of narratives upgraded simple media coverage to the level of foreign policy practitioners in both countries.

Despite that the Canadian broadcasters did not produce content in Russian, thus limiting access for the Russian audience, Russian media outlets took countermeasures against the Canadian coverage of Russian elections. A frequent $R T$ contributor, Canadian independent journalist, Eva Bartlett (@EvaKBartlett) claimed through her Facebook page that she came to Moscow to observe Russian protests without financial assistance from any broadcasters (August 11, 2019). ${ }^{9}$ Without any prior expertise on Russia, she made assumptions about the apathetic spirit of opposition protestors in Moscow and specifically denied $C B C$ 's narratives about "intense police repression." These messages ignited more than 100 comments, including a number of aggressive exchanges between the author and her followers, and marked 270 shares of the original post on Facebook. They were also widely used by Russian media outlets. For example, Bartlett's views were quoted by Vzglyad and EurAsia Daily, while Federal news agency and Izvestia interviewed her. Although in these interviews Bartlett admitted her limited knowledge about the situation in Russia and an absolute lack of Russian language skills which prevented her from gaining insights from protesters, she re-translated several common Russian anti-opposition media frames about foreign interference and US State Department funding (Bartlett 2019b, 2019c).

\section{Election Results: Canadian Perceptions}

The successful strategy developed by key oppositional players, in combination with demonstrations and media coverage of the events within the country and abroad, led to a significant shift in the election results compared to previous elections. Until the 2019 election, the ruling party, United Russia, was represented in the Moscow City Council by 38 deputies. On September 8, 2019, United Russia received only 25 of 45 seats in the city. A similar situation was seen in Khabarovsk region, Mari El Republic, Irkutsk, Birobidzhan, Penza, and Anadyr.

Having featured rallies and detentions earlier, Canadian broadcasters waited until the elections were over in Russia before making any assessments. Most of the outlets, with the exception of the

\footnotetext{
${ }^{9}$ On her blog, 'In Gaza and beyond' Bartlett (n.d.) defines herself as "an independent writer and rights activist with extensive experience in Syria and in the Gaza Strip."
} 
$C B C$ and the Globe and Mail, limited their coverage to reports from Reuters and Associated Press. The $C B C$, which has its correspondent, Chris Brown, stationed in Moscow, made an attempt, with the assistance of a few Russian scholars, to evaluate the election results on September $9^{\text {th }}$. On September $12^{\text {th }}$, the $C B C$ broadcast a 24-minute segment from Brown, which began with a comparison of Canadian and Russian elections. Brown (2019) stated that Canadian elections were "a lot more competitive, freer and unpredictable in terms of who was going to win than you would see in Russia." He expressed the view that the election outcome was much worse for the Kremlin than had been expected. But more than that, Brown presented insights based on background information about the situation in Russia that often is not typically provided to a Canadian audience. In particular, he mentioned how and why a narrative of a stable government differs in the two countries.

The Globe and Mail sent its London-based correspondent, Mark Mackinnon, to Moscow on the eve of their elections, and subsequently published four original articles between September $8^{\text {th }}$ and $12^{\text {th }}$. Mackinnon (2019b) fully described election results in various Russian regions, as well as the essence of Navalny's Smart Vote tactic, calling it controversial. In addition, the Globe and Mail featured Lyubov Sobol, the opposition candidate promoted by Navalny, whose registration to contest these elections was rejected, and followed up on police raids against addresses affiliated with Navalny's supporters across the country.

Russian authorities, capitalizing on the Western interference narrative in Russian media, made accusations against the Canadian media coverage of Russian elections. A Foreign Ministry representative, Ilya Timohov, outlined a strong new Russian narrative at a meeting of the Interim Federation Council Commission to Protect State Sovereignty and Prevent Interference in the Russian Federation's Domestic Affairs. Despite the fact that no concrete examples of the Canadian broadcasters' misconduct were given, the Canadian media was referenced in regard to their alleged information campaign against Russia and its existing regime, as well as attempts to influence the Russian population (Timohov 2019). The Russian Foreign Ministry seemed dissatisfied with the extensive reporting about the above-mentioned pre-election rallies and arrests. The Russian frame about this type of western media election interference was spread further in the country's media, carrying cross-national coverage to the point of absurdity.

\section{Conclusion}

Concluding this snapshot of cross-national media coverage of electoral campaigns, it is apparent that both countries report on the elections of their counterparts using certain media frames. However, the Canadian media directs its state narratives exclusively at an English-speaking audience, primarily local. Russian broadcasters and state institutions have both Russian- and English-language channels to transmit information. Russian-language resources target a Russianspeaking audience both in Russia and abroad, while English-language sources from Russia are directed at all English-speakers, including Canadians.

The content of Canadian and Russian reporting differs greatly. Canadian media and officials accuse Russia of election meddling, basing their charges on previous examples of similar violations proven by investigations and research (Communications Security Establishment 2017; 2019; Al-Rawi and Jiwani 2019). Russian outlets and authorities also accuse Canada by calling 
any media coverage, especially on election day, a form of interference (Timohov 2019). At the same time, Russian reporting both in English and in Russian contains a negative vocabulary and offensive tone which is not the norm in Canadian reporting (e.g., Filippov 2019b; Cunningham 2019). Canadian broadcasters feature the Russian opposition and its activity more than the Kremlin (e.g., Mackinnon 2019b), but generally do not produce insulting materials. In contrast, all the negativity in Russian media is abusive, using terms such as a "poster-boy politician," a "repeat offender," a "self-proclaimed champion of liberal values," a "pathetic fraud" having "racist blood," "two-faced Justin Trudeau," "Trudeaumania," "hypocrisy and duplicity of the smooth-talking liberals," etc. Finally, Elections Canada did not try to regulate media content outside of the country and reminded voters that election law permits people outside of the country to give their views on topics related to Canada's election (Burke 2020). In contrast, the Russian Central Election Commission and the Ministry of Foreign Affairs stressed that foreign media in their respective countries should obey the Russian election law when covering Russian elections (Timohov 2019).

In Canada, where citizens trust the system, the perception of threat to the process is external, and this notion is reflected in media coverage. In Russia, where citizens trust neither the system nor media coverage, the perception of threat is internal. The totally unexpected successes of the Russian opposition in this election period forced certain changes in Russian media coverage, as state-owned mainstream media outlets had to acknowledge the decrease in popularity for United Russia across the country.

This article has focused on cross-national media coverage during the Russian regional elections of September 2019 and Canadian federal elections of October 2019 in order to provide a snapshot of the positions and perceptions each country has about the other's electoral and political processes. What is important in the wider perspective, however, is the existence of certain over-arching narratives that frame each country's media discourse about the other. These media frames, largely negative ones in 2019, become interpretive tools for media consumers and ultimately translate not only elections but any event or phenomenon, using a familiar set of tropes, visual images, and linguistic associations. It is these narratives - invisible, assumed and often taken for granted - that this article has set out to explore, explain, and make visible. While these discourses remain in place it is unlikely that media, and by extension, public opinion about the other country, will shift. It will be important to keep these assumptions and biases on both sides in mind as the two countries endeavor to find common ground and work together on issues of international importance. 


\section{REFERENCES}

Akimushkina, Irina. 2019. "Canada is not 'a Northern extension of the USA." [In Russian.] Nezavisimaya Gazeta, January 27, 2019. http://www.ng.ru/dipkurer/2019-0127/10_7492_canada.html.

Al-Rawi, Ahmed and Yasmin Jiwani. 2019. "Russian Twitter trolls stoke anti-immigrant lies ahead of Canadian election." The Conversation, July 23, 2019. https://theconversation.com/russian-twitter-trolls-stoke-anti-immigrant-lies-ahead-ofcanadian-election-119144.

Bartlett, Eva (@EvaKBartlett). 2019. “I've been to many protests, in DC (2006, against Israeli bombings of Lebanon and Gaza), in Bil'in (at least 10 times, 2007), in Gaza (too many times to count), in Toronto (Quds day protests)." Facebook, August 11, 2019. https://www.facebook.com/100000000104830/posts/2618957821447529.

Bartlett, Eva. 2019b. "American Embassy actively promoted the August 10 'opposition' rally" (interview). [In Russian]. FAN, August 13, 2019. https://riafan.ru/1203382-eva-bartlettamerikanskoe-posolstvo-aktivno-reklamirovalo-miting-oppozicii-10-avgusta.

.2019c. "I saw attempts of provocations aimed at police" (interview). [In Russian]. Izvestia, August 17, 2019. https://iz.ru/911267/izvestiia/ia-videla-popytki-sprovotcirovat-politciiu.

. n.d. "About me." In Gaza and beyond, blog entry. Accessed on April 14, 2020. https://ingaza.wordpress.com/about-me/.

Bolotsky, Denis. 2019. “Trudeau's Liberals Face Uphill Battle in Canada's Heartlands Ahead of Federal Elections." Sputnik, October 18, 2019. https://sputniknews.com/us/201910181077087738-trudeaus-liberals-face-uphill-battle-incanadas-heartlands-ahead-of-federal-elections/.

Bradshaw, Samantha. 2018. "Securing Canadian Elections: Disinformation, Computational Propaganda, Targeted Advertising and What to Expect in 2019." Behind the Headlines: Research Paper Series 66 (3): 1-12.

Brown, Chris. 2019. "Understanding Vladimir Putin's grip on power: Interview with Chris Brown." CBC Front Burner September 12, 2019. https://www.cbc.ca/radio/frontburner/understanding-vladimir-putin-s-grip-on-power1.5281725 .

Burke, Ashley. 2020. "Social media users voiced fears about election manipulation during 2019 campaign, says Elections Canada." CBC News, January 30, 2020. https://www.cbc.ca/news/politics/elections-canada-social-media-monitoring-findings1.5444268 .

Chamberlain, P.R., 2010. "Twitter as a Vector for Disinformation." Journal of Information Warfare 9 (1): 11-17. 
Chomsky, Noam. 2002. Media Control: The spectacular achievements of propaganda. New York: Seven Stories Press.

Climenhaga, David. 2019. “An election's coming and the PM's treading water - where's a Russian to blame now that we need one?" Alberta Politics, blog entry, April 7, 2019. https://albertapolitics.ca/2019/04/an-elections-coming-and-the-pms-treading-water-wheresa-russian-to-blame-now-that-we-need-one/.

Communications Security Establishment. 2017. Cyber threats to Canada's democratic process. Ottawa: Government of Canada. https://cyber.gc.ca/sites/default/files/publications/csecyber-threat-assessment-e.pdf.

. 2019. 2019 Update: Cyber Threats to Canada's Democratic Process. Ottawa: Government of Canada. https://cyber.gc.ca/sites/default/files/publications/tdp-2019-report_e.pdf.

Council on Foreign Relations. 2018. "A Conversation with Justin Trudeau, Chrystia Freeland, and Jim Carr" video, 55:26. September 25, 2018. https://www.cfr.org/event/conversationjustin-trudeau-chrystia-freeland-and-jim-carr.

Cunningham, Finian. 2019. "Canada's furor over Trudeau's racist problems is only skin deep." $R T$, Op-ed, September 20, 2019. https://www.rt.com/op-ed/469259-trudeau-canadaindigenous-rights/.

De Vreese, Claes H. 2005. "News framing: Theory and typology." Information design journal \& document design 13 (1): 51-62.

Druckman, James N. 2005. "Media matter: How newspapers and television news cover campaigns and influence voters." Political communication 22 (4): 463-481.

Elections Canada. 2020. Report on the 43rd General Election of October 21, 2019. EC 94372, February 2020. https://www.elections.ca/res/rep/off/sta_ge43/stat_ge43_e.pdf.

Evans, Alfred B. 2011. "The failure of democratization in Russia: A comparative perspective.” Journal of Eurasian Studies 2 (1): 40-51.

Filippov, Artem. 2019a. "How Canada interfered in elections in other countries." [In Russian.] Vzglyad, April 23, 2019. https://vz.ru/world/2019/4/23/974520.html. . 2019b. "Canadian Indians are extirpated right at school." [In Russian.] Vzglyad, May 11, 2019. https://vZ.ru/world/2019/5/11/977091.html.

. 2019c. "The government of Canada plays the Russian card attempting to hide corruption." [In Russian.] Slovo i delo, May 11, 2019. https://slovodel.com/527704-pravitelstvo-kanadyrazygryvaet-rossiiskuyu-kartu-v-popytke-skryt-korrupciyu.

Foreign Policy CAN (@CanadaFP). 2019. “Canada is gravely concerned 1000+ peaceful protesters were detained in advance of upcoming \#Moscow elections. Freedom of assembly and expression are fundamental rights \& enshrined in constitution.” Twitter, July 29, 2019. https://twitter.com/canadafp/status/1155937471533727744. 
Gallacher, John and Marc Heerdink. 2019. "Measuring the effect of Russian Internet Research Agency information operations in online conversations." Defence Strategic Communications 6 (Spring): 155-198.

Global News. 2019. "Trudeau: Government taking steps to fight foreign election interference," video, 1:06. April 5, 2019. https://globalnews.ca/video/5134751/trudeau-governmenttaking-steps-to-fight-foreign-election-interference.

Government of Canada. 2019. "The Government of Canada's Plan to Safeguard Canada's 2019 Election." Canada.ca, Democratic Institutions, March 21, 2019. https://www.canada.ca/en/democratic-institutions/news/2019/03/speech-thegovernment-ofcanadas-plan-to-safeguard-canadas-2019-election.html.

Jardine, Eric. 2019. "A storm of misinformation is coming. Our federal election could be at risk." The Globe and Mail, April 16, 2019. https://www.theglobeandmail.com/opinion/article-astorm-of-misinformation-is-coming-our-federal-election-could-be-at/.

Jowett, Garth and Victoria O'Donnell. 2018. Propaganda \& Persuasion, 7th edition. Thousand Oaks: Sage Publications.

Katorzhnov, Dmitry. 2014. "Putin and the fifth column. Experts comment on President's words." [In Russian.] MK.RU, December 18, 2014. https://www.mk.ru/politics/2014/12/18/putin-ipyataya-kolonna-slova-prezidenta-kommentiruyut-eksperty.html.

Knight, Amy. 2019. "The Kremlin lashes out against the people, but Russians are no longer afraid to fight back." The Globe and Mail, July 30, 2019. https://www.theglobeandmail.com/opinion/article-the-kremlin-lashes-out-against-thepeople-but-russians-are-no-longer/.

Kolga, Marcus. 2019a. Stemming the VIRUS: Understanding and responding to the threat of Russian disinformation. Ottawa: Macdonald-Laurier Institute Publication. http://macdonaldlaurier.ca/files/pdf/20181211_MLI_Russian_Disinformation\%20PAPER FWeb.pdf. . 2019b. "Canada needs a plan to deal with hostile cyber campaigns." National Post, May 6, 2019. https://nationalpost.com/opinion/canada-needs-a-plan-to-deal-with-hostile-cybercampaigns.

. 2019c. "Russian disinformation is attacking our democracy and making us sick." The Star, February 21, 2019. https://www.thestar.com/opinion/contributors/2019/02/21/russiandisinformation-is-attacking-our-democracy-and-making-us-sick.html.

Kornilov, Vladimir. 2019. "Corruption benefits are described to Canada." [In Russian.] RIA Novosti, September 10, 2019. https://ria.ru/20190910/1558491839.html. 
Korso, Tim. 2019. 'Canadian Imam Urged Worshipers Not to Vote for 'Filthy Non-Muslim' Candidates Ahead of Election," with video of Younus Kathrada. Sputnik, October 22, 2019. https://sputniknews.com/us/201910221077120282-canadian-imam-worshipers-vote-forfilthy-non-muslim-candidates/.

Kozdra, Michał. 2018. "The Boundaries of Russian Identity Analysis of the Concept of Russkiy Mir in Contemporary Russian Online Media.” Lingua Cultura 12 (1): 61-66.

Kriel, Charles, and Alexa Pavliuc. 2019. "Reverse Engineering Russian Internet Research Agency Tactics through Network Analysis.” Defence Strategic Communication 6 (Spring): 199-227.

Linvill, Darren L. and Patrick L. Warren. 2018. "Troll factories: The internet research agency and state-sponsored agenda building." Resource Centre on Media Freedom in Europe, June, 2018. https://www.rcmediafreedom.eu/Publications/Academic-sources/Troll-FactoriesThe-Internet-Research-Agency-and-State-Sponsored-Agenda-Building.

Lough, John, Orysia Lutsevych, Peter Pomerantsev, Stanislav Secrieru, and Anton Shekhovtsov. 2014. "Russian influence abroad: Non-state actors and propaganda." Chatham House, Russia and Eurasia Programme Meeting Summary, October 24, 2014. https://www.chathamhouse.org/sites/default/files/field/field_document/20141024RussianIn fluenceAbroad.pdf.

Lyadov, Anton. 2019. "Ukrainians manage to disagree with Russians even in Canada." [In Russian] January 13, 2019. Russia 1 video, 9:28, https://www.vesti.ru/doc.html?id=3104005.

Mackinnon, Mark. 2019a. "Kremlin gearing up bid to permanently quash protest movement, Russian oligarch in exile warns." The Globe and Mail, September 6, 2019. https://www.theglobeandmail.com/world/article-kremlin-gearing-up-bid-to-permanentlysquash-protest-movement-russian/.

- "Putin's opponents cheer results as Russia's ruling party suffers setbacks in local elections." The Globe and Mail, September 9, 2019. https://www.theglobeandmail.com/world/article-putins-opponents-cheer-results-as-russiasruling-party-suffers/.

Maclean's. 2019. “National Leaders Debate 2019," video, 1:59:41, September 10, 2019. https://www.macleans.ca/politics/national-leaders-debate-2019-live-video-macleans-andcitytv/.

Martinov, Andrey. 2011. "Oppositionist gave his colleagues a broadside." [In Russian.] MK.RU, July 1, https://www.mk.ru/politics/2011/07/01/602169-oppozitsioner-obrushilsya-nakolleg.html. 
MFA Russia (@mfa_russia).2019.“March,2015,\#Quebec City.\#Police fired tear gas and clashed with protesters outside, after demonstrators gathered in the protest against austerity policies. See for yourselves. \#IsThisDemocracy." Twitter, July 30, 2019. https://twitter.com/mfa_russia/status/1156201738225029121.

Ministry of the Foreign Affairs of the Russian Federation. 2019. "Comment by the Information and Press Department regarding new anti-Russia sanctions adopted by the United States and Canada." March 15, 2019. http://www.mid.ru/ru/foreign_policy/news//asset_publisher/cKNonkJE02Bw/content/id/3573396?p_p_id=101_INSTANCE_cKNonkJ E02Bw\&_101_INSTANCE_cKNonkJE02Bw_languageId=en_GB.

Nanos Research. 2018. "Most Canadians believe that the Russian government is using social media to meddle in the elections of western democracies." CTV News and Nanos National Survey, August, 2018. http://www.nanos.co/wp-content/uploads/2018/08/2018-1239-CTV-JulyRussian-Election-Interference-Populated-report-w-tabs.pdf.

Navalny, Alexei. 2018. "How we will win a victory over the United Russia during elections. Smart Vote." [In Russian.] Navalny, blog entry. November 28, 2018. https://navalny.com/p/6017/.

Nelson, Chris. 2019. "Trudeau's more of a threat to Canada than Russia." The Calgary Herald, April 11, 2019. https://calgaryherald.com/opinion/columnists/nelson-trudeaus-more-of-athreat-than-russia/.

Oates, Sarah. 2014. "Russian state narrative in the digital age: Rewired propaganda in Russian television news framing of Malaysia airlines flight 17." American Political Science Association Annual Meeting, August 1, 2014. https://ssrn.com/abstract=2941192.

Oates, Sarah. 2016. "Russian media in the digital age: Propaganda rewired." Russian Politics 1 (4): 398-417.

Paul, Christopher and Miriam Matthews. 2016. "The Russian 'firehose of falsehood' propaganda model." Rand Corporation: 2-7.

Pazzano, Jasmine. 2019. "Moscow's local election has shaken all of Russia. Here's why." Global News, August 17, 2019. https://globalnews.ca/news/5775688/moscow-local-electionshakes-russia-heres-why/.

Pinchuk, Alina. 2019. “'A wave of repression has begun.' Who and why faces the prospect of persecution." [In Russian.] Radio Svoboda, February 7, 2019. https://www.svoboda.org/a/29757531.html.

PRISP. n.d. "Election campaigns by PRISP Centre." [In Russian.] Accessed on April 6, 2020. http://www.prisp.ru/experience/28-prisp-elections.

Putin, Vladimir. 2013. (Text version of an interview) "Visit to Russia Today television channel." Kremlin. Published on June 11, 2013. http://en.kremlin.ru/events/president/news/18319. 
Rocha, Roberto. 2018. "Data sheds light on how Russian Twitter trolls targeted Canadians." CBC News, August 3, 2018. https://www.cbc.ca/news/canada/russian-twitter-trolls-canadatargeted-1.4772397.

Rocha, Roberto. 2019. "Fears of election meddling on social media were overblown, say researchers." CBC News, November 3, 2019. https://www.cbc.ca/news/canada/socialmedia-bots-trolls-canadian-election-2019-1.5343210.

Roeder, Oliver. 2018. "Why We're Sharing 3 Million Russian Troll Tweets." FiveThirtyEight, July 31, 2018. https://fivethirtyeight.com/features/why-were-sharing-3-million-russiantroll-tweets/.

Russia in Canada (@RussianEmbassyC). 2019. "Blaming Moscow for fake \#meddling is pure disinformation. Given \#RussiaGate fiasco in the US, it's ridiculous to play the same card in Canada to distract public attention from real issues \#cndpoli." Twitter, Apr. 5, 2019. https://twitter.com/RussianEmbassyC/status/1114246378111111168.

Russian Congress of Canada (RCC) Board of Directors. 2019a. "RCC statement on CBC coverage of the Rossiya 1 report on the Ukrainian Canadian Diaspora." Russian Congress of Canada. February 10, 2019. http://russiancongresscanada.org/news-en/rcc-statement-on-cbccoverage-of-the-rossiya-1-report-on-the-ukrainian-canadian-diaspora/. . 2019b. "Open Letter to the Macdonald-Laurier Institute in reply to the publication of Marcus Kolga's report 'Stemming the Virus."' Russian Congress of Canada. February 23, 2019. http://russiancongresscanada.org/press-releases-en/open-letter-to-the-macdonaldlaurier-institute-in-reply-to-the-publication-of-marcus-kolgas-report-stemming-the-virus/.

Statistics Canada. 2016. “2016 Census of Population.” Statistics Canada Catalogue no. 98-400X2016187.

Sukhankin, Sergey. 2019. "The Western Alliance in the Face of the Russian (Dis) information Machine: Where Does Canada Stand?” The School of Public Policy Publications, University of Calgary, Research Paper 12:26.

The Post Millennial. 2020. "About us." February 18, 2020. https://www.thepostmillennial.com/page/about-us.

Timohov, Ilya. 2019. (Remarks). "Meeting of a working group of an interim Federation Council commission to protect state sovereignty and prevent the interference in the Russian Federation's domestic affairs." [In Russian]. Filmed on September 12, 2019. Federation Council video, $1: 23: 13$, http://council.gov.ru/events/news/107732/?hl=Рабочая\%20группа\%20временной\%20ко миссии \%20Совета\%20федерации \%20по\%20защите \%20государственного\%20сувере нитета\%20и\%20предотвращению\%20вмешательства\%20во\%20внутренние\%20дела \%20России. 
Thompson, Elizabeth. 2019. “'More needs to be done,' Gould says after some online election meddling detected." CBC News, October 28, 2019. https://www.cbc.ca/news/politics/election-misinformation-disinformation-interference1.5336662.

US House of Representatives Permanent Select Committee on Intelligence. 2018. "Schiff statement on release of Twitter ads, accounts and data." Press Releases, June 18, https://intelligence.house.gov/news/documentsingle.aspx?DocumentID=396.

Van Herpen, Marcel H. 2015. Putin's propaganda machine: Soft power and Russian foreign policy. Lanham, MD: Rowman and Littlefield.

Vivanco, Pablo. 2019a. "The end of Trudeaumania: Canadians are over PM's image obsession, lack of substance \& broken promises." $R T$, Op-ed. October 16, 2019. https://www.rt.com/oped/471051-trudeau-elections-promises-broken/. . 2019b. "Lack of alternatives, broken electoral system delivers 'win' for Trudeau." $R T$, Oped. October 22, 2019. https://www.rt.com/op-ed/471581-trudeau-victory-canada-electionsystem/.

Wilkerson, John and Andreu Casas. 2017. "Large-scale computerized text analysis in political science: Opportunities and challenges." Annual Review of Political Science 20: 529-544. 
Published by the Centre for European Studies at Carleton University, Ottawa, Canada

Available online at: https://ojs.library.carleton.ca/index.php/CJERS/index

The Canadian Journal of European and Russian Studies (CJERS - formerly Review of European and Russian Affairs) is an open-access electronic academic peer-reviewed journal: articles are subject to double-blind peer-review. Topics relate to the European Union, its Member States, the former Soviet Union, and Central and Eastern Europe. The journal is published by the Centre for

European Studies, an associated unit of the Institute of European, Russian and Eurasian Studies at Carleton University.

CJERS aims to provide an accessible forum for the promotion and dissemination of high quality research and scholarship.

\section{Contact:}

Carleton University

The Centre for European Studies

1103 Dunton Tower

1125 Colonel By Drive

Ottawa, ON K1S 5B6

Canada

Tel: +01 613 520-2600 ext. 3117; E-mail: CJERS@ carleton.ca

\section{Creative Commons License}

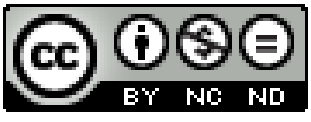

https://creativecommons.org/licenses/by-nc-nd/4.0/

This Working Paper is licensed under a Creative Commons Attribution-Non-Commercial-

No Derivs 4.0 Unported License (CC BY-NC-ND 4.0).

Articles appearing in this publication may be freely quoted and reproduced, provided the source is acknowledged. No use of this publication may be made for resale or other commercial purposes.

ISSN: 2562-8429

(C) 2019 The Author(s) 